\title{
CHARLES READ'S NOTES ON COLONIAL AGRIGULTURE
}

\author{
By CARL R. WoOdward
}

After graduation from Rutgers in 1914, Dr. Woodward taugbt in bigb scbool for $a$ year and then returned to our campus, where be bas remained ever since except for a leave of absence to complete bis doctorate at Cornell. His interest in agricultural bistory dates back to bis tbesis, The Development of Agriculture in New Jersey $1640-1880$, publisbed in 1927. He was joint autbor, with Ingrid N. Waller, of New Jersey's Agricultural Experiment Station I8801930, publisbed in 1932. Recently be bas been preparing a life of Charles Read and editing the manuscript notes written by Read in the Systema Agriculturae of Jobn Worlidge. Of this last work be gives an account bere. His book will appear sbortly.

MONG the treasured items of the Rutgers Library's A collection on agricultural history is a manuscript ex$\triangle$ ceptionally rich in data on colonial agriculture. It is a miscellany of notes, observations, records, and comments kept by Charles Read, prominent citizen of New Jersey for about thirty years prior to the Revolution. The entries are made on interleavings bound into a volume of Systema Agriculturae, by the English writer John Worlidge, the third edition, enlarged (London, I68I). In addition, there are copious notes on the margins of Worlidge's text. Altogether, when copied, the notes occupy more than 150 typed pages.

The manuscript was acquired in I 929 through the courtesy of the Burlington County Library and Mr. Charles A. Thompson, the county agricultural agent. It was coverless and browned with age, the edges worn away, the title page missing. The name of the author was nowhere in evidence. In the text, however, were several references that gave definite clues to the authorship, for example, "my farm in Springfield," "my plantation on Ancocas," "Ed. Tonkin, an honest neighbor," and similar comments. A persistent running down of these clues in time led to the conclusion, finally confirmed by a comparison of the handwriting with that of signed documents, that beyond doubt the author was Charles Read.

The authorship known, the notes at once assumed added significance. For Read was one of the outstanding figures of 
pre-Revolutionary New Jersey. Born in I7 I 5 , son of Charles Read, Sr., wealthy merchant and one time mayor of Philadelphia, he was related to the Logans, the Pembertons, and other prominent families of Philadelphia. He is reputed also to have been a relative of Deborah Read, wife of Benjamin Franklin. As a youth he went to England to complete his education, got a commission in the British navy, journeyed to the West Indies, where he married the daughter of a planter, returned to Philadelphia, and in I739 purchased the clerk's office at Burlington.

Thereupon he moved to that town and began a public career that was probably unparalleled in New Jersey colonial history. In the ensuing years he was admitted to the bar, and was, in turn or simultaneously, collector of the port of Burlington, clerk of the circuits, surrogate, justice of the peace, registrar, secretary of the Province, speaker of the Assembly, member of the Council, and justice (for a time chief justice) of the Supreme Court. He was colonel of militia, and as commissioner to treat with the Indians, he was instrumental in establishing the first government reservation for Indians, at Brotherton (now Indian Mills) in Burlington County. Besides his public offices, he had extensive private interests-he was a large land holder, with farms, plantations, and timber tracts amounting to many thousands of acres. More than a hundred land transactions are recorded in his name in the State Archives. He had a fishery on the Delaware below Trenton. Pioneer in the iron industry, it was his ambition to be New Jersey's greatest ironmaster. To this end he founded in the I 760 's four furnaces in Burlington County - at Taunton, Etna, Atsion, and Batstow -for the manufacture of iron from the deposits of bog ore. His extraordinary influence in the affairs of the colony was the subject of comment at the time of his death (I774) in the diary of his contemporary Aaron Leaming. Leaming by inference accords him the title of "prime minister," and adds, "from I 747 to I77 I he had the almost absolute rule of Governor, Council and Assembly."

With all his political and commercial enterprises, Read appears to have been a man of broad cultural interests. He was a charter member of the Philadelphia Library Company, that pioneer group assembled in the $1730^{\circ}$ 's under the directing genius of Benjamin Franklin, and officially chartered in I742. Evi- 
dently he was a real "friend of the library," for the catalog of the library, printed by Franklin in I74I, lists a four-volume set of Cato's Letters "given by Charles Read, Esq." After changing his residence to Burlington, he became interested in providing library facilities for this city, and was one of the founders of the Library Company of Burlington. This library, which appears to have been modeled somewhat after the Philadelphia library, was chartered in $175^{8}$ by King George II. In I768 Read was elected to the American Philosophical Society, that distinguished company of savants which numbered among its members the Franklins - father and son, the botanist John Bartram, and William Logan, son of the colonial statesman and scientist, James Logan.

In the midst of his many-sided activities, Read found time for the pursuit of agriculture. His notes contain records of his own experiments with crops and with livestock. He gave special attention to red clover, writing, "I sowed $12{ }^{1 b}$ pr Acre of a rich Meadow $\&$ it was not too thick $\&$ I cut $31 / 2$ Load pr Acre $\mathrm{y}^{\mathrm{e}} \mathrm{I}^{\text {st }}$ Crop." His observations on the growth of red clover are strikingly similar to Benjamin Franklin's, made at about the same time and presumably in the same region. Perhaps Read and Franklin collaborated in their study of this and other crops. An entry of unique interest is a recipe for making glue from sturgeon dated $\mathrm{I} 76_{3}$, from a Mr. Jackson, of London. It is headed by the notation: "In a letter from London to B. Franklin Esqr. $w^{\text {eh }}$ he sent me."

The notes also include extracts from letters which Read received from friends relating to various agricultural enterprises. Here is a typical passage:

Extracts from Mr. Trenchard's ${ }^{1}$ Letter to me of $4^{\text {th }} 8^{\text {br }} 175^{6}$ respecting an Experiment he made $w^{\text {th }}$ two oxen at my request. That he fed 2 oxen 6 weeks $\mathrm{w}^{\text {th }}$ white clover-that they eat 3 square perch in 2 days (An acre will keep at this rate 2 cattle 105 days) that they fatted more by this Method while confined at that diet Mowed \& given 3 times a day than in double ye time in Excellent pasture \& well Watered-that he thinks each ox will make I load of dung pr $\mathrm{m}^{\mathrm{o}} \mathrm{w}^{\text {th }}$ the Litter.

In addition, Read notes odd comment on numerous farm matters reflecting the local practices of the time, as well as observations made on his travels. He appears also to have been

${ }^{1}$ Probably Judge George Trenchard, of Salem. 
well read in the agricultural literature of his day. His notes abound with abstracts from contemporary works on agriculture, mainly by English writers. Among the works cited are Richard Bradley's New Improvements of Planting and Gardening (London, I739), William Ellis' The Practical Farmer (London, I732), Duhamel du Monceau's A Practical Treatise of Husbandry (London, I759), and Philip Miller's Gardener's Dictionary (London, I73I), ${ }^{2}$ all of which are listed in the early catalogs of the Philadelphia Library Company. Read quotes at length from other works of Bradley, from the writings of Hale, of Hitt, of Hartlib, and of Mortimer, and from the transactions of agricultural societies of the British Isles. In all, he draws directly or indirectly from about thirty different works -which would represent a substantial agricultural library for his day. Occasionally he finds these authors' recommendations do not correspond with his own experience, and he accordingly notes exception. These portions of the manuscript are of special significance since they suggest the influence of English writers upon American agriculture.

The notes are rich, also, in the experiences of Read's friends and acquaintances. Altogether, he refers to II 7 different persons-their advice, their customary practices, their farm experiences, the results of their experiments, some of which were carried out at Read's suggestion. Those mentioned include leading citizens in the colony. For example, he discloses Governor Belcher's secret of "good Cask cider"-hang a small bag of hops inside the barrel and "bung it tight up." A diagram is shown of the cattle stalls in the barn of the Governor's "worthy friend," Robert Ogden, of Elizabeth. The semi-tropical garden and greenhouse at Petersboro, country estate of the famous Colonel Peter Schuyler, of Newark, are glimpsed in directions for growing orange trees, given Read by Schuyler's gardener. Meanwhile Teunis Dey, of Bergen, charter member of the Board of Trustees of Queen's College, whose mansion served as General Washington's headquarters in I780, makes known a method of preventing birds from pulling corn. Then there is a recipe for making grape jam from "Mrs. Stevens." Read was

\footnotetext{
2 One of the most valued items of the Philadelphia Library Company is a copy of Miller's Gardener's Dictionary, the first gift of books made to the library. It was donated in 1732 by the genial London Quaker, Peter Collinson, for many years correspondent of Franklin and Bartram, and friend of Charles Read.
} 
closely associated in affairs of state with John Stevens, who served as president of the New Jersey Convention that ratified the Constitution in 1787 , and this was probably his wife. Col. John Stevens, pioneer in steam navigation, was their son. Other public leaders mentioned in the notes include Capt. Richard Somers, of Great Egg Harbor; Judge William Hancock, of Salem; Peter Kemble, of Morristown, member of the Council; and Samuel Smith, of Burlington, historian, and treasurer of the Colony.

The "Mr. Warrell," “Mr. Saltar," and "Mr. Kinsey" referred to were in all probability Joseph Warrell of Trenton, Attorney-General of the Province; Richard Saltar, of Monmouth County, member of the Council and brother-in-law of Mordecai Lincoln, the New Jersey ancestor of Abraham Lincoln; and James Kinsey of Burlington, member of the Assembly and subsequently chief justice of the New Jersey Supreme Court. Read notes, respectively, Mr. Warrell's experience in fattening cattle on pasture, Mr. Saltar's method of plowing corn, and Mr. Kinsey's recipe for a medicine for jaundice.

The only American publication of consequence at this time on the subject of agriculture was Essays Upon Field Husbandry in New England, by Jared Eliot-Connecticut clergyman, physician, and farmer. These essays, six in all, appeared serially between I748 and I759; and were published in a single volume in I760. Read followed Eliot's essays closely, and commented on them freely throughout his notes. There is evidence, too, that he corresponded with Eliot, and procured seeds from him.

Since the notes were in large measure contemporary with Eliot's Essays, a comparison of the two is of interest. In style they are scarcely comparable. Even though lacking in coherence, Eliot's works are finished essays, while Read's notes, never intended for publication, are a pot pourri of ideas, observations, and records on a wide variety of topics, assembled over three decades, sketchy and necessarily incomplete. Eliot approaches the subject in a philosophical manner, from the standpoint of national economy, and almost invariably works up to a religious interpretation. Read, on the other hand, treats agriculture from the practical standpoint of the farm as a business unit. He is more concerned with the profit of the individual farm enterprise than with the farmers' relation to the national 
welfare. Many of his passages suggest the modern textbook on farm management.

Then, too, Read's notes cover a much wider field of subject matter than do Eliot's Essays. Eliot deals mainly with the management of the soil, and the growing of certain field crops. Emphasis is given to the drainage of marshes and of meadows, the improvement of worn-out soils, the use of manures, and the growing of clover. Read treats the same subjects, but also discusses the culture of various fruits and vegetables which Eliot barely mentions or omits entirely. He includes a valuable table of dates for the planting, the blossoming, and the ripening of numerous vegetable crops. He devotes more than a page to peaches, commenting, "A peach orchard was a scheme I have long intended to putt in execution."

Read also gives considerable space to farm structures and farm implements, presenting in minute detail plans and specifications for the construction of barracks, cow sheds, fences, gates, and other essential adjuncts to the farm. He quotes Bradley's General Treatise of Husbandry and Gardening on bee husbandry - a subject not mentioned by Eliot. He deals in detail with the problems of the housewife, giving recipes for the preparation and preservation of various kinds of food, and advice on making garments, controlling vermin, preparing beverages, concocting medicines, and making soap. Commercial fisheries also are discussed.

Most notably in the treatment of animal and dairy husbandry does Read surpass Eliot. His notes on the breeding and care of horses, on the management of cattle for dairy and other purposes, on swine and sheep husbandry, on the preparation of dairy products, and on the handling of pork are especially complete and enlightening.

Of all the sources of information on agriculture in the American colonies of which I have knowledge, the Read manuscript, with one exception, is the richest in practical detail. That exception is the two-volume treatise American Husbandry, published anonymously in London in I775. But Read's notes have the distinction of antedating this more complete work by a number of years. 